\title{
An Investigation of Thai Listed Firms' Financial Distress Using Macro and Micro Variables*
}

\author{
Sunti Tirapat \\ Chulalongkorn University, Thailand \\ Aekkachai Nittayagasetwat \\ National Institute of Development Administration, Thailand
}

The emergence of the economic crisis in Thailand in 1997 is an interesting case for academic studies. Internationally, it had a contagion effect, spreading to countries in Asia and in other regions. Domestically, it caused a great many industrial and corporate bankruptcies. The Thai economy had been relatively stable since 1984. The recent development in 1997, however, produced a sudden economic slump resulting in closures of many Thai corporations. Using a logit regression, this study develops a macro-related micro-crisis investigation model. The significance of the model is in its ability to bridge a firm's sensitivity to macroeconomic conditions and its financial characteristics in order to explore a firm's financial distress. The findings indicate that macroeconomic conditions are critical indicators of potential financial crisis for a firm. The article shows that the higher a firm's sensitivity to inflation, the higher the firm's exposure to financial distress.

Keywords: bankruptcy, financial distress, prediction model, and Thailand crisis.

\section{Introduction}

In 1997, an Asian financial crisis emerged. From Thailand, the crisis rapidly spread throughout the region. The swiftness and the confounding effects of the "Tom Yam Kung" crisis have raised several

*Financial support for this research was provided by the Listed Company Association, Thailand. The authors appreciate comments and suggestions by four anonymous referees and participants at presentations at the Third Annual European FMA Conference (Barcelona 1999), the Sixth Annual Conference of the Multinational Finance Society (Toronto 1999), and the Eleventh Annual PACAP/FMA Finance Conference (Singapore 1999).

(Multinational Finance Journal, 1999, vol. 3, no. 2, pp. 103-125)

(C) Multinational Finance Society, a nonprofit corporation. All rights reserved.

DOI: $10.17578 / 3-2-2$ 
interesting economic questions. ${ }^{1}$ What was the root of the problem? Why was the crisis 'contagious'? What triggered the speculative attack? These issues have already been investigated by prominent economic scholars. Numerous causes of the crisis have been proposed, ranging from the role of financial panic (Rachel and Sachs [1998]) to a nexus of moral hazard problems (Corsetti, Pensenti, and Roubini [1998]). ${ }^{2}$

The crisis, however, has provided an opportunity to investigate another area of interest, the role of corporate bankruptcy. The impact of the crisis has resulted in a large number of Thai firms going bankrupt in 1997. ${ }^{3}$ Since the massive bankruptcy is an exceptional case in Thailand, this article aims to seek the cause of this event. Prior articles on predicting bankruptcy focus primarily on financial variables such as financial ratios, cash flows, or accounting opinions. ${ }^{4}$ Many studies have been conducted in developed countries because data are readily available. In emerging markets, however, this line of research is scarce since, in growing economies, bankrupt firms are actually rare. ${ }^{5}$ The crisis provides us with an opportunity to investigate the prediction model in developing countries such as Thailand. An investigation of the financial distress model may be of interest and provide some insights into this area of research since the Thai environment may differ from that of the developed markets on several aspects. First, the institutional structure of the financial sector in Thailand can be characterized as a bank-centered financial system, in contrast with that of a market-based

1. "Tom Yam Kung" is a famous Thai dish and it became the name of the 1997 economic crisis spreading from Thailand.

2. The speculative attack literature is reviewed by Flood and Marion (1998). The contagious nature of the crisis has been investigated by Eichengreen, Rose, and Wyplosz (1996) and more recently by Glick and Rose (1998).

3. During 1992-1995, the growth of average net incomes of firms listed in the Stock Exchange of Thailand was around $22 \%$ while in the 1996 it declined to $-31.3 \%$.

4. Studies that use only financial ratios include early works such as Beaver (1966) and Altman (1968). Much of the recent work is discussed in Altman and Saunders (1998). Studies that incorporate accountant opinions include Hopwood et al. (1989) and Flagg et al. (1991). Studies that use only financial ratios include early works such as Beaver (1966) and Altman (1968), and Altman, Haldeman, and Narayanan (1977). Much of the recent work is discussed in Altman and Saunders (1998) and Zavgren (1983). Studies that incorporate accountant opinions include Hopwood et al. (1989), Flagg et al. (1991).

5. For example, in Thailand fewer than 10 companies listed in the Stock Exchange of Thailand were financially distressed during 1987-1994. 
system such as that in the U.S. The credits from financial institutions (commercial banks and finance companies) are about 5.5 times larger than funds raised (in form of equity and bonds) from capital markets in 1994 and 16.7 times larger than funds raised in 1997. Secondly, the ownership structure in Thailand is highly concentrated. The average percentage of common shares owned by the three largest shareholders in the ten largest firms is around 44 percent. $^{6}$ The typical Thai conglomerate is controlled by family and highly leveraged by local financial institutions. This structure has led to inefficient investments before the 1997 financial crisis. The ratio of earnings before interest and taxes (EBIT) over interest expenses declined from 5.78 in 1994 to 1.49 in 1997, while the leverage ratio rose from 1.5 to 2.95 during the same period. Thirdly, anecdotal evidence shows that although the accounting standards in Thailand are similar to those of other international standards such as the International Accounting Standard (IAS) or the Financial Accounting Standard Board (FASB), the accounting practices are of concern. ${ }^{7}$ Hence, it is interesting to see whether or not financial ratios can appropriately explain the causes of failure of firms in developing countries such as Thailand.

In addition, an investigation of financially distressed firms in emerging markets, in our view, should take economic conditions into account since these firms are typically small and operating in an open economy. Moreover, as a firm's accounting system is subject to accounting standard, e.g., Generally Accepted Accounting Principles (GAAP), it seldom reflects immediate changes in a firm's financial situation when a crisis strikes the overall economy. Therefore, accounting variables alone may not adequately explain a firm's financial distress, and the firm's sensitivity to macroeconomic factors should be taken as a significant explanatory variable to indicate a firm's financial distress. In other words, firms that are more sensitive to economic shocks should be more prone to financial distress than firms that are less sensitive. This article attempts to incorporate the macroeconomic factors in the investigation of financially distressed firms. The purpose of incorporating macroeconomic variables is to capture the sensitivity

6. See La porta, Lopez-de-Silanes, Shleifer, and Vishy (1998), which compile ownership concentration of 45 developed and developing countries.

7. Alba, Claessens, and Djankov (1998) point out that accounting and auditing practices in Thailand may be due to the lack of strong self-regulatory organizations in the auditing and accounting profession and a shortage of well-qualified accountants and auditors. 
to change in macroeconomic factors. This perspective, in our view, is more consistent with the Thai situation. Using the two-stop logit approach, this study develops a macro-related micro-crisis investigation model. It is found that the sensitivity of firms to economic conditions plays a major role in differentiating the financially distressed companies from the non-distressed ones.

The article is organized as follows: Section II reviews prior research. The sample and methodology are discussed in section III. Empirical results of the model are reported in section IV. The discussion of the findings and conclusions are presented in section $\mathrm{V}$.

\section{Literature Review}

\section{A. Prediction of Bankruptcy}

Bankruptcy prediction models were pioneered by Beaver's (1966) univariate test and Altman's (1968) multivariate discriminant analysis. Both articles document that financial variables can be used to predict bankruptcy. Since then, prediction of corporate failure has been a topic of much interest and more recent works have extended this line of research in three areas: statistical techniques, definitions of bankruptcy, and a greater variety of explanatory variables. For example, Ohlson (1980) utilized the logit and probit analysis to estimate the probability of bankruptcy. The adjustments of estimation bias resulting from oversampling, such as weights based on prior probabilities in the estimation process and optimal cut-off point, are discussed in Zmijewski (1984). The problems of pooling data due to a small number of samples are addressed in Zavgren (1983) .

The second area of extension has dealt with the definitions of bankruptcy. For example, a model that distinguishes between financially distressed firms that survive and financially distressed firms that ultimately go bankrupt has been investigated. Gilbert, Menon, and Schwartz (1990) find different explanatory financial variables for these two groups of firms. In addition, a sample firm may be classified into more than two categories (bankrupt or nonbankrupt) and the classification probabilities can be estimated by the multinomial logit technique. For example, Poston, Harmon, and Gramlich (1994) assigned firms into one of three groups according to each firm's financial condition: turnarounds, business failures, and survivors. They 
find that financial ratios are not so useful in distinguishing between financially distressed firms that are able to turn around and those that are unable to avoid failure. Johnsen and Melicher (1994), on the other hand, suggest that by using multinomial logit models, the classification errors can be significantly reduced.

The third area involves some adjustment of explanatory variables either by covering additional variables other than financial ratios or industry-adjusted ratios. For example, Hopwood, McKeown, and Mutchler (1989) and Flagg, Giroux, and Wiggins (1991) find that a qualified opinion is significant in distinguishing financially distressed firms. Some studies include macroeconomic variables to control for changes in the business environment. Rose and Giroux (1982) examine 28 business cycle indicators and find that economic conditions affect the failure process. Mensah (1983) evaluates the bankruptcy model using the price-level adjusted (SPL) data. The findings indicate that SPL data do not significantly improve bankruptcy prediction. Finally, Platt and Platt (1990) control for industry differences by using industrynormalizing ratios. The industry-relative framework results in stable bankruptcy models. Therefore, industrial growth has a significant effect on corporate failure. Furthermore, Platt and Platt (1991) investigate the stability and completeness of a bankruptcy model based on industryrelative ratios compared to that of unadjusted ratios. ${ }^{8}$

Both models yield stable parameter estimation. The industryrelative specification, however, appears to provide incremental information not contained in the model based on the unadjusted ratios.

\section{B. Prediction of Currency and Banking Crises}

Another strand of related research concerns the prediction of currency and banking crises; for example, Demirguc-Kunt and Detragiache (1997), Eichengreen and Rose (1998). These studies are motivated by the recent spate of crises ${ }^{9}$ in Europe (Finland, Sweden), Latin America (Mexico, Argentina) and Asia (Thailand, Indonesia). Kaminsky and Reinhart (1996), in analyzing a sample of 20 crises, report the importance of macroeconomic factors in a crisis. They document that

8. The specification of their models includes four financial ratios, sales growth, and the interaction of industry output and financial ratios.

9. Caprio and Klingebiel (1996) document 49 banking crises in the 1970s and 1980s; and 33 crises occurred over the first six years of the present decade. 
output, the stock market, and the real exchange rate usually peak about a year before the onset of a banking crisis. Real interest rates and bank deposits rise in the period leading up to the crisis. Demirguc-Kunt and Detragiache (1997) apply a multivariate logit model to the determinants of banking in a sample of developed as well as developing countries between 1980 and 1994. They find that in general, low growth and high inflation are associated with the probability of a banking crisis. Eichengreen and Rose (1998) restrict their sample to cover only banking crises in emerging markets from 1975 through 1992. They apply a multivariate probit model to nine economic variables; four of their variables are "international" in nature, three are "domestic", and two are "external" in nature. Their results suggest that banking crises in emerging countries tend to occur in response to a conjuncture of unfavorable developments in international markets and domestic imbalances. Specifically, rising industrial-country interest rates precipitate banking crises: a one-percent increase in interest rates is associated with an increase in the probability of banking crises of around three percent.

Kaminsky, Lizondo, and Reinhart (1997) examine the empirical evidence on 25 currency crises and compare the merits of alternative approaches in providing early indications of the crises. They document that the best track record includes exports, deviations of the real exchange rate from the trend, the ratio of broad money supply to gross international reserves, output, and equity prices. Kaminsky and Reinhart (1996) also investigate 76 currency crises and 26 banking crises and find that banking and currency crises are closely related in the aftermath of financial liberalization, with banking crises generally preceding currency crashes.

\section{Data and Methodology}

\section{A. Sample and Data}

The sample includes firms listed in the Stock Exchange of Thailand (SET) that experienced financial distress in 1997. Financially distressed firms are defined in this article as firms that either (1) were closed down by governmental authorities (all of which were banks and finance companies) or (2) were required by the Bank of Thailand or SET to submit restructuring plans (these companies were designated as $\mathrm{C}$ or 
$\mathrm{SP}^{10}$ by the Exchange). There were 459 firms listed in the SET in 1996, of which 55 were financially distressed by this definition. Firms that were first listed on the SET in 1995 or later and firms with incomplete data are excluded. The resulting sample consists of 341 non-financially distressed firms and 55 financially distressed firms. The characteristics of firms in the sample are reported in table 1.

\section{B. Method}

Although some prior research, e.g., Rose, Andrews, and Giroux (1982), have included macroeconomic variables in the prediction model, this study differs on one important aspect. The purpose of incorporating macroeconomic variables is not to control for changes in the business environment but rather to capture the sensitivity to change in macroeconomic factors. This perspective, in our view, is more consistent with the Thai situation.

The sensitivity of firms to economic conditions is expected to play a major role in differentiating the financially distressed companies from the non-distressed ones. For example, an enterprise, which has a high systematic risk corresponding to macroeconomic conditions, e.g., growth of industrial production, inflation, changes in interest rates, and changes in money supply (M2), may be exposed to the possibility of financial distress. In this article, the multi-factor model represents the relationship between the firm's stock return and the firm's sensitivity to macroeconomic factors. In other words, changes in macroeconomic factors and the firm's sensitivity to those changes will affect the firm's stock return. Then, the relationship between the firm's probability of financial distress and the firm's stock return is such that a firm, which encounters a high return, will have a low probability of financial distress. This process needs a two-step analysis whereby changes in macroeconomic factors and the firm's sensitivity to those factors affect the firm's stock return, with a firm's stock return in turn having an effect on the firm's probability of financial distress. Therefore, the twostep logit can be applied as used in Maddala (1986). This line of methodology has also been used in Thomson (1992) and Theodossiou et al. (1996). For example, the study by Thomson (1992) uses two-step

10. The SET posts a supervision sign of "C" (the filing for compliance) or "SP*" (the suspension or the temporary prohibition of trading until the causes of delisting are eliminated) against a listed company and the firm must submit the SET documents supporting the company's financial position. 
TABLE 1. Sample Characteristics

\begin{tabular}{lcrr}
\hline Description & Full Sample & Distressed & Non-distressed \\
\hline Total assets & $19,772,150.10$ & $21,690,440.67$ & $19,462,748.39$ \\
Earnings before interest and taxes & $512,615.58$ & $-84,358.06$ & $608,901.65$ \\
Total equity & $3,371,051.44$ & $2,683,971.35$ & $3,481,870.81$ \\
Total debt & $16,401,098.66$ & $19,006,469.32$ & $15,980,877.58$ \\
Number of observations & 396 & 55 & 341 \\
\hline
\end{tabular}

Note: The figures are expressed in thousand baht. As of December 31, 1996, the exchange rate between the US $\$$ and the Thai baht is US\$ $1=25.7$ baht. However, after the Ministry of Finance of Thailand changed the exchange rate regime from the currency basket to the managed float system on July 2, 1997, the currency exchange of US\$ 1 as of December 31, 1997, was equal to 48.15 baht. 
logit regression approach as a link between official bank failure and bank insolvency. Theodossiou et al (1996) also reexamine the economic factors determining the decision to acquire a financially distressed firm using a sequential response logit (SRL) model. In their model, acquisition, nonacquisition, and wealthy outcomes are expressed as a two-stage sequence of binary outcomes, healthy/distress in stage one, and acquisition/non-acquisition in stage two.

Therefore, logistic discriminant analysis used in this article will apply this two-step idea in order to estimate return on a firm's stock, and then the estimated stock return will be used as a representation of a macroeconomic sensitivity indicating a firm's financial distress. The estimated stock return calculated from the multi-factor model is designed as a link to the micro-crisis model. In other words, the firm's estimated return calculated from the multi-factor (or macroeconomic factors) model represents the macro effects incorporated into the microcrisis prediction model.

Several researchers, e.g., Beaver (1966) and Scott (1981), confirm the relationship between a firm's probability of bankruptcy and the firm's stock return. But because the firm's actual stock return reflects both the systematic risk and firm-specific risk, the motivation of the two-step is to capture only the systematic risk in which the economic crisis has affected the firms in the economy as a whole. In general, the micro-crisis model and the related macro factors imply the following specifications (the indirect test):

$$
\operatorname{prob}\left(Y_{i}=1\right)=\frac{1}{1+\exp \left(-Z_{i}\right)},
$$

where

$$
\begin{gathered}
Z_{i}=a+b \hat{R}_{i}+\sum_{j} c_{j, i}, \\
\hat{R}=\beta_{0, i}+\sum_{k} \beta_{k, i} \hat{F}_{k},
\end{gathered}
$$

$Y_{i}$ is assigned the value of 1 if firm $i$ is financially distressed and the value of zero otherwise, $\operatorname{Prob}\left(Y_{i}=1\right)$ is the probability with which firm $i$ is classified as a financially distressed firm, $Z_{i}$ is a linear function in which $a, b$, and $c$ are coefficients of variables, $X_{j, i}$ is the financial 
characteristic $j$ of firm $i, \hat{F}_{k}$ is the estimated macroeconomic factor $k$, and $\hat{R}_{i}$ is the estimated monthly stock return of firm $i$, specified as a linear function of the macroeconomic factor $\hat{F}_{k}$.

The probability, $\operatorname{Prob}\left(Y_{i}=1\right)$, depends on the logistic function of a linear relationship of a set of variables including $\hat{R}_{i}$ and $X_{i, j}$. The estimated monthly stock return of the firm $i, \hat{R}_{i}$, can be calculated from a multi-factor model in which the estimated macroeconomic factors, $\hat{F}_{k}$, are used to develop the model. The relationship between a firm's probability of financial distress and its stock return has been pointed out by Beaver (1968) and Scott (1981). While the first study showed the decline of a firm's stock return as the firm approached failure, the second confirmed that the probability of bankruptcy depended on the firm's stock return. Therefore, a firm's stock return is a good reflection of the market expectation of the firm's probability of financial distress.

The actual stock return, $R_{i}$, however, represents both systematic risk and firm-specific risk; e.g., $R_{i}=\beta_{0, i}+\beta_{1, i} F+e_{i}$, in which $F$ represents the systematic factor(s) and $e_{i}$ contains the firm-specific risk. Since the firm's financial characteristics, discussed later, are related to the firmspecific risk, the use of the actual stock return, together with the firm's financial characteristics, as explanatory variables to the model will be a double consideration of the firm-specific risk. In addition, the 1997 economic crisis has systematically hit the overall listed firms, so the motivation of this study is an attempt to find a proxy for systematic risk corresponding to the firm's bankruptcy risk. The estimation specification of $\hat{R}_{i}$ will carve out the firm-specific risk and capture only the systematic risk of the firm. Then the use $\hat{R}_{i}$ and financial characteristics combines the systematic and firm-specific risks as the representation of explanatory variables to the macro-related micro-crisis model without a redundancy of the firm-specific risk consideration.

\section{Financial variables}

The set of variables, $X_{j, i}$, represents financial characteristics of the firm $i$. Shivaswamy, Hoban, and Matsumoto (1993) studied thirteen research papers and summarized the frequency of financial ratios used in those papers. The most frequently used ratios were: current ratio, leverage ratio, and profitability ratio. Altman and Altman et al. (1968, 1983, 1984, 1994) developed numerous models predicting bankruptcy and financial distress. In particular, Altman (1984) surveyed studies on 
business failure models in various countries and reviewed the utilization of variable profiles employed in those studies. The most frequently used financial ratios were: working capital to total assets, retained earnings to total assets, earnings before interest and taxes to total assets, market value of equity to total liabilities, and sales to total assets.

However, the literature in this area of finance and accounting shows that researchers usually base their models on the capital, assets, management, earnings, and liquidity of a firm, which are the so-called CAMEL categories. Following Salchenberger, Cinar, and Lash (1992), the financial ratios are categorized only from each element of the CAMEL framework. The set of variables, $X_{j}$, following the CAMEL categories is selected as follows:

Capital: $X_{1}=$ book value of stockholders' equity / total assets (SETA) Assets: $X_{2}=$ retained earnings / total assets (RETA)

Management and Earnings: $X_{3}=$ operating income / net sales (OINS) Liquidity: $X_{4}=$ net working capital / total assets (WCTA)

These four variables will be used as the financial characteristics of the firms in the sample and as explanatory factors to the model.

The dependence on a set of financial ratios as a sole explanatory set of variables, however, has raised a question of whether they are sufficient to explain a firm's financial situation when the crisis strikes the economy as a whole. The reason is that a firm's accounting system is prone to accounting standard, e.g., Generally Accepted Accounting Principles (GAAP), and it may not represent a good rationale for a firm's financial distress due to the economic slump. So a firm's sensitivity to macroeconomic factors should be included, as explanatory variables to the firm's financial distress and the estimated stock return which incorporates the effect of the firm's sensitivity to macroeconomic factors should be a good representation of the macroeconomic factor for explaining the firm's probability of financial distress.

\section{Multi-factor model}

Demirguc-Kunt and Detragiache (1997) use ten variables as macroeconomic factors in their logit model. However, only four variables (real quarterly GDP growth, real short-term interest rate, inflation, and M2 money supply to international reserves) are significant variables, which can explain the probability of banking crises. These four macroeconomic factors have also been widely used 
econometrically. For the sample of Thai economic conditions, monthly growth of the production-manufacturing index will provide more observations than will the use of quarterly real GDP growth. Therefore, the macro-factors, $F_{k}$, are selected as follows:

$F_{1}=$ monthly growth of the production manufacturing index (PMI)

$F_{2}=$ monthly inflation or changes in the consumer price index (CPI)

$F_{3}=$ monthly changes in interest rates (INT)

$F_{4}=$ monthly changes in M2 money supply (MS2)

The estimated changes in the above economic conditions will be used to calculate the estimated stock returns of firm $i$ according to the following equation:

$$
\hat{R}_{i}=\beta_{0, i}+\beta_{1, i} \hat{F}_{1}+\beta_{2, i} \hat{F}_{2}+\beta_{3, i} \hat{F}_{3}+\beta_{4, i} \hat{F}_{4},
$$

where $\beta_{0, i}$ is the intercept and $\beta_{1, i}, \beta_{2, i}, \beta_{3, i}$, and $\beta_{4, i}$ are coefficients of variables representing the systematic risks or the sensitivity of firm $i$ to the changes in industrial production, consumer price index, interest rates, and M2 money supply, respectively.

It should be noted that for the specification in the indirect test (equation 1), the estimated stock return is a complete reflection of the sensitivity of the firm to macroeconomic conditions as well as the macroeconomic conditions. Alternatively, the effect of a firm's sensitivity of macroeconomic factors on the probability of the firm's financial distress can be specified as follows (the direct test):

where

$$
\operatorname{prob}\left(Y_{i}=1\right)=\frac{1}{1+\exp \left(-Z_{i}\right)}
$$

$$
Z_{i}=a+\sum_{k} b_{k} \beta_{k, i}+\sum_{j} c_{j} X_{j, i}+e_{i}
$$

The above model tests the effect of the sensitivity of firms in terms of financial distress to four macroeconomic conditions: growth of industrial production, inflation, changes in interest rates, and changes in M2 money supply. In this direct test, the explanatory factors of the firm's probability of financial distress include the firm's sensitivity to macroeconomic factors and the firm's financial characteristics. 
The systematic risks, $\beta_{k, i}$, of firm $i$ are obtained from the regression of the monthly stock returns of the firm $i$ at time $t_{i}, R_{i, t}$ on the monthly macroeconomic factors at time $t_{i}, F_{j, t}{ }^{11}$ The equation is such that:

$$
R_{i}=\beta_{0, i}+\beta_{1, i} F_{1, t}+\beta_{2, i} F_{2, t}+\beta_{3, i} F_{3, t}+\beta_{4, i} F_{4, t}+e_{i, t},
$$

where $e_{i, t}$, the error term, represents the firm-specific risk of the firm $i$ at time $t$.

\section{Empirical Results}

The descriptive statistics of variables are reported in table 2, while the results of the macro-related micro-crisis prediction models, both indirect and direct tests, are presented in table 3 . The results indicate that the estimated stock return variable corresponding to the estimated changes in macroeconomic factors is significantly different from zero. The negative sign suggests that a firm with a higher estimated rate of return has a lower probability of financial distress. The rationale has been pointed out by Beaver (1966) as the declining of a firm's stock return signaling the firm's vulnerability to the possibility of bankruptcy. The significance of this variable (at the 5\% significance level) also indicates the importance of macroeconomic conditions and those conditions can strongly influence the probability of the firm's financial distress.

The results of the alternative direct specification (equation 2) are also reported in table 3 . The results indicate that the only significant macro factor is the sensitivity of the firms to inflation or changes in the consumer price index. In other words, only the systematic risk of a firm exposed to inflation affects the probability of the firm's financial distress. The sign suggests that the more a firm faces inflation risk, the higher the firm's vulnerability to the risk of financial distress.

For both alternative models (the indirect test in equation 1 and the direct test in equation 2), the financial characteristics such as stockholders' equity to total assets (SETA) and working capital to total assets (WCTA) are significant at the $1 \%$ significance level. The relationship is such that the greater the SETA and WCTA ratios, the

11. The monthly data of the stock return and the macroeconomic factors were collected starting from January 1987 to December 1996. Therefore, there are 120 monthly observations that are employed in regressing the stock return over the macroeconomic factors. 
TABLE 2. Descriptive Statistics of Variables for the Full, the Non-distressed, and the Distressed Samples

\begin{tabular}{|c|c|c|c|c|c|c|c|c|c|c|}
\hline \multirow{2}{*}{$\begin{array}{l}\text { Model } \\
\text { Variable }\end{array}$} & \multicolumn{3}{|c|}{ Full Sample (396 Firms) } & \multicolumn{3}{|c|}{ Non-distressed Sample (341 Firms) } & \multicolumn{3}{|c|}{ Distressed Sample (55 Firms) } & \multirow{2}{*}{$\begin{array}{l}\text { Mean } \\
\text { Difference }\end{array}$} \\
\hline & Max & Min & Mean & Max & Min & Mean & Max & Min & Mean & \\
\hline$R_{i}$ & 3.5138 & -11.5892 & $\begin{array}{l}-.2962 \\
{[.76]}\end{array}$ & 3.5138 & -2.5304 & $\begin{array}{l}-.2214 \\
(2.3)^{* *}\end{array}$ & .9808 & -11.5892 & $\begin{array}{l}-.7602 \\
(4.16)^{* * *}\end{array}$ & $\begin{array}{c}.5389 \\
\{6.43\}^{* * *}\end{array}$ \\
\hline$\beta_{P M I}$ & 5.6707 & -1.441 & $\begin{array}{c}.0374 \\
{[.48]}\end{array}$ & 1.6086 & -1.441 & $\begin{array}{l}.0243 \\
(-.82)\end{array}$ & 5.6707 & -.8706 & $\begin{array}{r}.1185 \\
(-1.34)\end{array}$ & $\begin{array}{c}-.0942 \\
\{4.45\}^{* * *}\end{array}$ \\
\hline$\beta_{C P I}$ & 26.303 & -17.5141 & $\begin{array}{l}1.1273 \\
{[5.1]}\end{array}$ & 17.8946 & -17.5141 & $\begin{array}{c}.6371 \\
(-3.8) * * *\end{array}$ & 26.303 & -6.9741 & $\begin{array}{c}4.166 \\
(-4.89) * * *\end{array}$ & $\begin{array}{l}-3.5288 \\
\{2.03\}^{* * *}\end{array}$ \\
\hline$\beta_{i n t}$ & .4366 & -1.6489 & $\begin{array}{l}-.0664 \\
{[.14]}\end{array}$ & .4366 & -.5001 & $\begin{array}{l}-.0586 \\
(1.65)\end{array}$ & .1775 & -1.6489 & $\begin{array}{l}-.1143 \\
(2.67) * * *\end{array}$ & $\begin{array}{c}.0557 \\
\{4.19\}^{* * *}\end{array}$ \\
\hline$\beta_{M S 2}$ & 26.6999 & -18.5894 & $\begin{array}{c}1.5073 \\
{[3.42]}\end{array}$ & 11.7656 & -18.5894 & $\begin{array}{c}1.314 \\
(-2.05)^{* *}\end{array}$ & 26.6999 & -5.3813 & $\begin{array}{c}2.706 \\
(-2.82)^{* * * *}\end{array}$ & $\begin{array}{l}-1.3921 \\
\{2.49\}^{* * *}\end{array}$ \\
\hline
\end{tabular}




\section{TABLE 2. (Continued)}

B. Financial Characteristic

\begin{tabular}{|c|c|c|c|c|c|c|c|c|c|c|}
\hline SETA & 1.003 & -2.1488 & .4201 & $\begin{array}{c}1.0030 \\
{[.24]}\end{array}$ & -2.1488 & .4601 & $\begin{array}{c}.7051 \\
(7.26)^{* * *}\end{array}$ & -1.1681 & $\begin{array}{c}.1718 \\
(7.41)^{* * *}\end{array}$ & $\begin{array}{c}.2883 \\
\{1.06\}\end{array}$ \\
\hline RETA & 1.3293 & -3.0053 & .1007 & $\begin{array}{c}1.3293 \\
{[.30]}\end{array}$ & -3.0053 & .1331 & $\begin{array}{c}.4259 \\
(3.13) * * *\end{array}$ & -2.9265 & $\begin{array}{l}-.098 \\
(4.6)^{* * *}\end{array}$ & $\begin{array}{c}.2308 \\
\{3.06\}^{* * *}\end{array}$ \\
\hline OINS & 7.195 & -17.1278 & .0893 & $\begin{array}{c}7.195 \\
{[1.1]}\end{array}$ & -17.1278 & .1193 & $\begin{array}{c}.42 \\
(1.83)^{*}\end{array}$ & -3.4021 & $\begin{array}{l}-.0965 \\
(1.29)\end{array}$ & $\begin{array}{c}.2158 \\
\{2.76\}^{* * *}\end{array}$ \\
\hline WCTA & 5.3238 & -44.2817 & -.405 & $\begin{array}{r}5.3238 \\
{[2.43]}\end{array}$ & -44.2817 & -.2145 & $\begin{array}{c}.3336 \\
(4.64)^{* * *}\end{array}$ & -7.5143 & $\begin{array}{l}-1.5864 \\
(3.86)^{* * *}\end{array}$ & $\begin{array}{c}1.3719 \\
\{1.67\}^{* *}\end{array}$ \\
\hline
\end{tabular}

Note: $R_{i}=\beta_{0, i}+\beta_{1, i} F_{1, t}+\beta_{2, i} F_{2, t}+\beta_{3, i} F_{3, t}+\beta_{4, i} F_{4, t}+e_{i, t}$ The macroeconomic variables are from monthly data during 1987-1996. $\dot{R}_{i}$ is the estimated monthly stock return of the firm $i$. $\beta_{P M I}$ represents the systematic risks or the sensitivity of a firm to the changes in industrial production. $\beta_{C P I}$ represents the systematic risks or the sensitivity of a firm to the changes in consumer price index. $\beta_{I N T}$ represents the systematic risks or the sensitivity of a firm to the changes in interest rates. $\beta_{M S 2}$ represents the systematic risks or the sensitivity of a firm to the changes in M2 money supply. SETA represents the ratio of stockholders' equity to total assets. RETA represents the ratio of retained earnings to total assets. OINS represents the ratio of operating income to net sales. WCTA represents the ratio of working capital to total assets. Parentheses include the standard errors in [ ], $t$-values, for $\mathrm{H}_{0}$ : variances are equal, in ( ), and $F$-values, for $\mathrm{H}_{0}$ : means are not significantly different from zero, in \{\}$. * * * * *$, and $*$ denote statistical significance at the $.01, .05$, and .1 levels, respectively. 
TABLE 3. The Macro-related Micro-crisis Prediction Models: Estimated Parameters and Wald Chi-square Statistics in Parentheses

\begin{tabular}{lcllc}
\hline & $\begin{array}{c}\text { Estimates of } \\
\text { Coefficients }\end{array}$ & Elasticity $^{\mathrm{a}}$ & $\begin{array}{l}\text { Estimates of } \\
\text { Coefficients }\end{array}$ & Elasticity $^{\mathrm{b}}$ \\
\hline Constant & -.9036 & $\mathrm{n} / \mathrm{a}$ & -1.1033 & $\mathrm{n} / \mathrm{a}$
\end{tabular}

Macroeconomic Factor

$-.503$

$(5.69)^{* *}$

$\beta_{P M I}$

$\beta_{C P I}$

$\beta_{I N T}$

$\beta_{M S 2}$

Financial Characteristic

\begin{tabular}{lcccc} 
SETA & -3.5065 & .7899 & -3.1373 & .6993 \\
& $(18.64)^{* * *}$ & & $(14.66)^{* * *}$ & \\
RETA & -.3395 & .0675 & -.5313 & .0038 \\
& $(.28)$ & & $(.65)$ & \\
OINS & .163 & .1874 & .1077 & .0129 \\
& $(.52)$ & & $(.39)$ & \\
WCTA & -.1228 & .2046 & -.1171 & .1985 \\
& $(7.12)^{* * *}$ & & $(6.8)^{* * *}$ & \\
\multirow{2}{*}{-2 Log L } & & & & \\
Model Chi-Square & $60.06^{* * *}$ & & 253.330 & \\
\end{tabular}

Note: For model $1 \operatorname{prob}\left(Y_{i}=1\right)=\frac{1}{1+\exp \left(-Z_{i}\right)}$, where $Z_{i}=a+b \hat{R}_{i} \sum_{j}+c_{j} X_{j, i}$. For model $2 \operatorname{prob}\left(Y_{i}=1\right)=\frac{1}{1+\exp \left(-Z_{i}\right)}$, where $Z_{i}=a+\sum_{k} b_{k} \beta_{k, i}+\sum_{j} c_{j} X_{j, i}+e_{i}$.

$\hat{R}_{i}$ is the estimated monthly stock return of the firm $i . \beta_{P M I}$ represents the systematic risks or the sensitivity of a firm to the changes in industrial production. $\beta_{C P I}$ represents the systematic risks or the sensitivity of a firm to the changes in consumer price index. $\beta_{I N T}$ represents the systematic risks or the sensitivity of a firm to the changes in interest rates. $\beta_{M S 2}$ represents the systematic risks or the sensitivity of a firm to the changes in M2 money supply. SETA represents the ratio of stockholders' equity to total assets. RETA represents the ratio of retained earnings to total assets. OINS represents the ratio of operating income to net sales. WCTA represents the ratio of working capital to total assets. Parentheses include the standard errors in [ ], $t$-values, for $\mathrm{H}_{0}$ : variances are equal, in ( ), and $F$-values, for $\mathrm{H}_{0}$ : means are not significantly different from zero, in \{\}$. * * *, * *$, and $*$ denote statistical significance at the 
TABLE 4. The Full-sample Test for Model 1

\begin{tabular}{|c|c|c|c|c|c|c|}
\hline \multirow{2}{*}{$\begin{array}{l}\text { Cutoff } \\
\text { Point }\end{array}$} & \multicolumn{2}{|c|}{$\begin{array}{l}\text { Distress Prediction } \\
\text { Accuracy }\end{array}$} & \multicolumn{2}{|c|}{$\begin{array}{c}\text { Non-distressed Prediction } \\
\text { Accuracy }\end{array}$} & \multicolumn{2}{|c|}{$\begin{array}{l}\text { Total Prediction } \\
\text { Accuracy }\end{array}$} \\
\hline & Amount & $\%$ & Amount & $\%$ & Amount & $\%$ \\
\hline 0 & 55 & $100.00 \%$ & 0 & $0.00 \%$ & 55 & $13.89 \%$ \\
\hline .1 & 48 & $87.27 \%$ & 205 & $60.12 \%$ & 253 & $63.89 \%$ \\
\hline .2 & 33 & $60.00 \%$ & 294 & $86.22 \%$ & 327 & $82.58 \%$ \\
\hline .3 & 21 & $38.18 \%$ & 323 & $97.95 \%$ & 344 & $86.87 \%$ \\
\hline .4 & 13 & $23.64 \%$ & 334 & $97.95 \%$ & 347 & $87.63 \%$ \\
\hline .5 & 8 & $14.55 \%$ & 336 & $98.53 \%$ & 344 & $86.87 \%$ \\
\hline 6 & 6 & $10.91 \%$ & 338 & $99.12 \%$ & 344 & $86.87 \%$ \\
\hline .7 & 4 & $7.27 \%$ & 339 & $99.41 \%$ & 343 & $86.62 \%$ \\
\hline .8 & 3 & $5.45 \%$ & 339 & $99.41 \%$ & 342 & $86.36 \%$ \\
\hline .9 & 2 & $3.64 \%$ & 339 & $99.41 \%$ & 341 & $86.11 \%$ \\
\hline 1 & 0 & $0.00 \%$ & 341 & $100.00 \%$ & 341 & $86.11 \%$ \\
\hline
\end{tabular}

Note: For model $1 \operatorname{prob}\left(Y_{i}=1\right)=\frac{1}{1+\exp \left(-Z_{i}\right)}$, where $Z_{i}=a+b \hat{R}_{i} \sum c_{j} X_{j, i}$, $\hat{R}_{i}=\beta_{0, i}+\sum \beta_{k, i} \hat{F}$. The sample consists of 396 firms in which 341 firms are nondistressed and 55 firms are financially distressed in 1997.

TABLE 5. The In-sample Test for Model 1

\begin{tabular}{|c|c|c|c|c|c|c|}
\hline \multirow{2}{*}{$\begin{array}{l}\text { Cutoff } \\
\text { Point }\end{array}$} & \multicolumn{2}{|c|}{$\begin{array}{l}\text { Distress Prediction } \\
\text { Accuracy }\end{array}$} & \multicolumn{2}{|c|}{$\begin{array}{c}\text { Non-distressed Prediction } \\
\text { Accuracy }\end{array}$} & \multicolumn{2}{|c|}{$\begin{array}{c}\text { Total Prediction } \\
\text { Accuracy }\end{array}$} \\
\hline & Amount & $\%$ & Amount & $\%$ & Amount & $\%$ \\
\hline 0 & 30 & $100.00 \%$ & 0 & $0.00 \%$ & 30 & $12.99 \%$ \\
\hline .1 & 25 & $83.33 \%$ & 154 & $76.62 \%$ & 179 & $77.49 \%$ \\
\hline .2 & 15 & $50.00 \%$ & 185 & $92.04 \%$ & 200 & $86.58 \%$ \\
\hline .3 & 15 & $50.00 \%$ & 195 & $97.02 \%$ & 210 & $90.91 \%$ \\
\hline .4 & 12 & $40.00 \%$ & 199 & $99.01 \%$ & 211 & $91.34 \%$ \\
\hline .5 & 10 & $33.33 \%$ & 199 & $99.01 \%$ & 209 & $90.48 \%$ \\
\hline .6 & 10 & $33.33 \%$ & 199 & $99.01 \%$ & 209 & $90.48 \%$ \\
\hline .7 & 6 & $20.00 \%$ & 199 & $99.01 \%$ & 205 & $88.75 \%$ \\
\hline .8 & 5 & $16.67 \%$ & 199 & $99.01 \%$ & 204 & $88.31 \%$ \\
\hline .9 & 4 & $13.33 \%$ & 199 & $99.01 \%$ & 203 & $87.88 \%$ \\
\hline 1 & 0 & $0.00 \%$ & 201 & $100.00 \%$ & 201 & $87.01 \%$ \\
\hline
\end{tabular}

Note: For model $1 \operatorname{prob}\left(Y_{i}=1\right)=\frac{1}{1+\exp \left(-Z_{i}\right)}$, where $Z_{i}=a+b \hat{R}_{i} \sum c_{j} X_{j, i}$,

$\hat{R}_{i}=\beta_{0, i}+\sum \beta_{k, i} \hat{F}$. The sample is divided into two subsamples: $60 \%$ of the full sample as the in-sample (learning sample) and $40 \%$ of the full sample as the out-sample (holdout sample). 
TABLE 6. The Out-sample Test for Model 1

\begin{tabular}{|c|c|c|c|c|c|c|}
\hline \multirow{2}{*}{$\begin{array}{l}\text { Cutoff } \\
\text { Point }\end{array}$} & \multicolumn{2}{|c|}{$\begin{array}{c}\text { Distress Prediction } \\
\text { Accuracy }\end{array}$} & \multicolumn{2}{|c|}{$\begin{array}{c}\text { Non-distressed Prediction } \\
\text { Accuracy }\end{array}$} & \multicolumn{2}{|c|}{$\begin{array}{c}\text { Total Prediction } \\
\text { Accuracy }\end{array}$} \\
\hline & Amount & $\%$ & Amount & $\%$ & Amount & $\%$ \\
\hline 0 & 25 & $100 \%$ & 0 & $0.0 \%$ & 25 & $15.15 \%$ \\
\hline .1 & 22 & $88 \%$ & 103 & $73.57 \%$ & 125 & $75.76 \%$ \\
\hline .2 & 18 & $72 \%$ & 120 & $85.71 \%$ & 138 & $83.64 \%$ \\
\hline .3 & 13 & $52 \%$ & 126 & $90.00 \%$ & 139 & $84.24 \%$ \\
\hline .4 & 11 & $44 \%$ & 133 & $95.00 \%$ & 144 & $87.27 \%$ \\
\hline .5 & 11 & $44 \%$ & 135 & $96.43 \%$ & 146 & $88.49 \%$ \\
\hline .6 & 5 & $20 \%$ & 136 & $97.14 \%$ & 141 & $85.46 \%$ \\
\hline .7 & 3 & $12 \%$ & 137 & $97.86 \%$ & 140 & $84.85 \%$ \\
\hline .8 & 2 & $8 \%$ & 137 & $97.86 \%$ & 139 & $84.24 \%$ \\
\hline .9 & 2 & $8 \%$ & 137 & $97.86 \%$ & 139 & $84.24 \%$ \\
\hline 1 & 0 & $0 \%$ & 140 & $100.00 \%$ & 140 & $84.85 \%$ \\
\hline
\end{tabular}

Note: For model $1 \operatorname{prob}\left(Y_{i}=1\right)=\frac{1}{1+\exp \left(-Z_{i}\right)}$, where $Z_{i}=a+b \hat{R}_{i} \sum c_{j} X_{j, i}$, $\hat{R}_{i}=\beta_{0, i}+\sum \beta_{k, i} \hat{F}$. The sample is divided into two subsamples: $60 \%$ of the full sample as the in-sample (learning sample) and $40 \%$ of the full sample as the out-sample (holdout sample).

TABLE 7. The Full-sample Test for Model 2

\begin{tabular}{|c|c|c|c|c|c|c|}
\hline \multirow{2}{*}{$\begin{array}{l}\text { Cutoff } \\
\text { Point }\end{array}$} & \multicolumn{2}{|c|}{$\begin{array}{c}\text { Distress Prediction } \\
\text { Accuracy }\end{array}$} & \multicolumn{2}{|c|}{$\begin{array}{l}\text { Non-distressed Prediction } \\
\text { Accuracy }\end{array}$} & \multicolumn{2}{|c|}{$\begin{array}{c}\text { Total Prediction } \\
\text { Accuracy }\end{array}$} \\
\hline & Amount & $\%$ & Amount & $\%$ & Amount & $\%$ \\
\hline 0 & 25 & $100 \%$ & 0 & $0.00 \%$ & 25 & $15.15 \%$ \\
\hline .1 & 22 & $88 \%$ & 103 & $73.57 \%$ & 125 & $75.76 \%$ \\
\hline .2 & 18 & $72 \%$ & 120 & $85.71 \%$ & 138 & $83.64 \%$ \\
\hline .3 & 13 & $52 \%$ & 126 & $90.00 \%$ & 139 & $84.24 \%$ \\
\hline .4 & 11 & $44 \%$ & 133 & $95.00 \%$ & 144 & $87.27 \%$ \\
\hline .5 & 11 & $44 \%$ & 135 & $96.43 \%$ & 146 & $88.49 \%$ \\
\hline .6 & 5 & $20 \%$ & 136 & $97.14 \%$ & 141 & $85.46 \%$ \\
\hline .7 & 3 & $12 \%$ & 137 & $97.86 \%$ & 140 & $84.85 \%$ \\
\hline .8 & 2 & $8 \%$ & 137 & $97.86 \%$ & 139 & $84.24 \%$ \\
\hline .9 & 2 & $8 \%$ & 137 & $97.86 \%$ & 139 & $84.24 \%$ \\
\hline 1 & 0 & $0 \%$ & 140 & $100.00 \%$ & 140 & $84.85 \%$ \\
\hline
\end{tabular}

$$
\begin{aligned}
& \text { Note: For model } 2 \operatorname{prob}\left(Y_{i}=1\right)=\frac{1}{1+\exp \left(-Z_{i}\right)}, \text { where, } \\
& \qquad Z_{i}=a+\sum_{k} b_{k} \beta_{k, i}+\sum_{j} c_{j} X_{j, i}+e_{i} .
\end{aligned}
$$

The sample consists of 396 firms in which 341 firms are non-distressed and 55 firms are financially distressed in 1997. 
TABLE 8. The In-sample Test for Model 2

\begin{tabular}{|c|c|c|c|c|c|c|}
\hline \multirow{2}{*}{$\begin{array}{l}\text { Cutoff } \\
\text { Point }\end{array}$} & \multicolumn{2}{|c|}{$\begin{array}{c}\text { Distress Prediction } \\
\text { Accuracy }\end{array}$} & \multicolumn{2}{|c|}{$\begin{array}{c}\text { Non-distressed Prediction } \\
\text { Accuracy }\end{array}$} & \multicolumn{2}{|c|}{$\begin{array}{l}\text { Total Prediction } \\
\text { Accuracy }\end{array}$} \\
\hline & Amount & $\%$ & Amount & $\%$ & Amount & $\%$ \\
\hline 0 & 30 & $100.00 \%$ & 0 & $0.00 \%$ & 30 & $12.99 \%$ \\
\hline .1 & 26 & $86.67 \%$ & 153 & $76.12 \%$ & 179 & $77.49 \%$ \\
\hline .2 & 17 & $56.67 \%$ & 183 & $91.05 \%$ & 200 & $86.58 \%$ \\
\hline .3 & 15 & $50.00 \%$ & 195 & $97.02 \%$ & 210 & $90.91 \%$ \\
\hline .4 & 13 & $43.33 \%$ & 199 & $99.01 \%$ & 212 & $91.78 \%$ \\
\hline .5 & 11 & $36.67 \%$ & 199 & $99.01 \%$ & 210 & $90.91 \%$ \\
\hline .6 & 9 & $30.00 \%$ & 199 & $99.01 \%$ & 208 & $90.04 \%$ \\
\hline .7 & 8 & $26.67 \%$ & 199 & $99.01 \%$ & 207 & $89.61 \%$ \\
\hline .8 & 5 & $16.67 \%$ & 199 & $99.01 \%$ & 204 & $88.31 \%$ \\
\hline .9 & 4 & $13.33 \%$ & 200 & $99.50 \%$ & 204 & $88.31 \%$ \\
\hline 1 & 0 & $0.00 \%$ & 201 & $100.00 \%$ & 201 & $87.01 \%$ \\
\hline
\end{tabular}

Note: For model $2 \operatorname{prob}\left(Y_{i}=1\right)=\frac{1}{1+\exp \left(-Z_{i}\right)}$, where

$$
Z_{i}=a+\sum_{k} b_{k} \beta_{k, i}+\sum_{j} c_{j} X_{j, i}+e_{i} .
$$

The sample is divided into two subsamples: $60 \%$ of the full sample as the in-sample (learning sample) and $40 \%$ of the full sample as the out-sample (holdout sample).

TABLE 9. The Out-sample Test for Model 2

\begin{tabular}{|c|c|c|c|c|c|c|}
\hline \multirow{2}{*}{$\begin{array}{l}\text { Cutoff } \\
\text { Point }\end{array}$} & \multicolumn{2}{|c|}{$\begin{array}{l}\text { Distress Prediction } \\
\text { Accuracy }\end{array}$} & \multicolumn{2}{|c|}{$\begin{array}{c}\text { Non-distressed Prediction } \\
\text { Accuracy }\end{array}$} & \multicolumn{2}{|c|}{$\begin{array}{l}\text { Total Prediction } \\
\text { Accuracy }\end{array}$} \\
\hline & Amount & $\%$ & Amount & $\%$ & Amount & $\%$ \\
\hline 0 & 30 & $100.00 \%$ & 0 & $0.00 \%$ & 30 & $12.99 \%$ \\
\hline .1 & 26 & $86.67 \%$ & 153 & $76.12 \%$ & 179 & $77.49 \%$ \\
\hline .2 & 17 & $56.67 \%$ & 183 & $91.05 \%$ & 200 & $86.58 \%$ \\
\hline .3 & 15 & $50.00 \%$ & 195 & $97.02 \%$ & 210 & $90.91 \%$ \\
\hline .4 & 13 & $43.33 \%$ & 199 & $99.01 \%$ & 212 & $91.78 \%$ \\
\hline .5 & 11 & $36.67 \%$ & 199 & $99.01 \%$ & 210 & $90.91 \%$ \\
\hline 6 & 9 & $30.00 \%$ & 199 & $99.01 \%$ & 208 & $90.04 \%$ \\
\hline .7 & 8 & $26.67 \%$ & 199 & $99.01 \%$ & 207 & $89.61 \%$ \\
\hline .8 & 5 & $16.67 \%$ & 199 & $99.01 \%$ & 204 & $88.31 \%$ \\
\hline .9 & 4 & $13.33 \%$ & 200 & $99.50 \%$ & 204 & $88.31 \%$ \\
\hline 1 & 0 & $0.00 \%$ & 201 & $100.00 \%$ & 201 & $87.01 \%$ \\
\hline
\end{tabular}

Note: For model $2 \operatorname{prob}\left(Y_{i}=1\right)=\frac{1}{1+\exp \left(-Z_{i}\right)}$, where

$$
Z_{i}=a+\sum_{k} b_{k} \beta_{k, i}+\sum_{j} c_{j} X_{j, i}+e_{i}
$$

The sample is divided into two subsamples: $60 \%$ of the full sample as the in-sample (learning sample) and $40 \%$ of the full sample as the out-sample (holdout sample). 
lower the probability of financial distress. Also, table 3 reports the elasticities, as defined in Theodossiou, et al. (1996), which measure the importance of the variables in the model. ${ }^{12}$ It can be seen that SETA and $\hat{R}_{i}$, for model 1 , and SETA and $b_{C P I}$, for model 2, are the most important variables, consistent with the Wald chi-square statistics.

Tables 4-9 show the predictive ability of the macro-related microcrisis prediction models at various cut-off points. Since type I errors are more costly than type II errors ${ }^{13}$, the study attempts to determine a cutoff point that correctly discriminates the distressed firms at a greater number than does the non-distressed firms or, in other words, in which type I errors are approximately smaller than type II errors. On average, the cut-off point at .1 seems to be optimal, indicating that a firm that has a probability of financial distress of $10 \%$ or over will be classified as a distressed firm and a firm that has a probability under $10 \%$ will be classified as a non-distressed firm. The prediction results for the indirect model (equation 1) are shown in table 4-6. At the cut-off point of .1, the total prediction accuracy equals to $63.89 \%$ for the full-sample test, $77.49 \%$ for the in-sample test, and $75.76 \%$ for the out-sample test as shown in table 4-6. The prediction results for the direct model (equation 2) are shown in table 7-9. At the cut-off point of .1, the total prediction accuracy equals to $68.43 \%$ for the full-sample test, $77.49 \%$ for the in-sample test, and $70.91 \%$ for the out-sample test as shown in table 7-9. The out-sample predictive ability of over $70 \%$ for both models signifies promising outcomes of this study.

\section{Conclusions and Discussion}

This article employed the 1997 economic crisis in Thailand as a case study. Using logit analysis, the model attempts to portray corporate bankruptcy caused by economic collapse as systematic risk. The macrorelated micro-crisis exploration model developed in this study has two specifications. The first specification (the indirect test) uses firms'

12. Unlike the logit coefficients, the elasticity is independent of measurement units for the variables.

13. Type I errors is the probability of a failed firm misclassified as an unfailed firm, and type II error is the probability of an unfailed firm misclassified as a failed firm. can be defined as the misclassification of the failed firm into the unfailed firm and type II errors can be defined as the misclassification of the unfailed firm into the failed firm. 
estimated stock returns calculated from the estimated changes in macroeconomic variables and firms' sensitivities to those macro variables as proxies of macro-related factors, while the second specification (the direct test) uses firms' sensitivities to macro variables as proxies for macroeconomic factors. The contribution of the model is to bridge a firm's sensitivity to macroeconomic conditions and its financial characteristics in order to investigate the firm's financial distress.

The results are promising and confirm that macroeconomic conditions are important factors in determining a firm's possibility of financial crises. The estimated stock return variable shows significance in the indirect-test specification (equation 1) and the sensitivity-toinflation variable is also significant at the .01 level in the direct-test specification (equation 2). Since 1996-1997, the Thai economy showed signs of a steep decline causing negative returns for equity investors. The empirical findings demonstrate that, in an economic crisis, the higher or less negative a firm's return, the lower the probability of the firm's financial distress. Inflation is the most crucial variable because the higher a firm's sensitivity to inflation, the more likely the firm's exposure to financial distress.

For testing the predictive ability of the model, the study uses the cutoff point at .1 to separate financially distressed firms from nondistressed firms because type I errors are quite costly, relative to type II errors. For both specifications, the predictive ability or accuracy ranges between $60-80 \%$ of the sample. An out-sample test of predictive ability confirms that the model has an accuracy of over $70 \%$ of the holdout sample.

In conclusion, the article develops the investigation model using the 1997 Thailand financial crisis. The model incoporates the firms' sensitivity to macroeconomic variables and their financial characteristic. It will be useful in providing warning signals of upcoming crises so that policy makers can seek protective measure in order to immunize the economy and protect against contagious, potentially lethal financial diseases.

\section{References}

Alba, P.; Claessens, S.; and Djankov, S. 1998. Thailand's Corporate financing and governance structures: Impact on firms' competitiveness. Conference 
on thailand's dynamic economic recovery and competitiveness. May 20-21, 1998, UNCC, Bangkok, Thailand.

Altman, E. I. 1968. Financial ratios, discriminant analysis and the prediction of corporate bankruptcy. The Journal of Finance 23 (September): 589-609.

Altman, E. I. 1983. Multidimensional graphics and bankruptcy prediction: a comment. Journal of Accounting Research 21(Spring): 297-299.

Altman, E. I. 1984. The Success of business failure prediction models: an international survey. Journal of Banking and Finance 8: 171-198.

Altman, E. I. 1994. Corporate distress diagnosis: Comparisons using linear discriminant analysis and neural network (the Italian experience). Journal of Banking and Finance 18: 505-529.

Altman, E. I. and Saunders, A. 1998. Credit risk measurement: Developments over the last 20 years. Journal of Banking and Finance 21: 1721-1742.

Barnes, P. 1987. The analysis and use of financial ratios: A review article. Journal of Business Finance and Accounting 14: 449-461.

Beaver, W. H. 1966. Financial ratios as predictors of failure. Empirical research in accounting: selected studies. Journal of Accounting Research 4 (Supplement).

Caprio, G. and Klingebiel, D. 1996. Dealing with bank insolvencies: Cross country experience, The World Bank, Washington, D.C.

Corsetti, G.; Pesenti, P.; and Roubini N. 1998. What Caused the Asian currency and financial crisis? Unpublished Manuscript.

Demirguc-Kunt, A. and Detragiache, E. 1997. The determinants of banking crises: Evidence from developing and developed countries. International Monetary Fund Working Paper.

Eichengreen, B.; Rose, A. K.; and Wyplosz, C. 1996. Contagious currency crises. NBER Working Paper No. 5681.

Eichengreen, B. and Rose, A. K. 1998. Staying Afloat when the wind shifts: external factors and emerging-market banking crises. NBER Working Paper No.6370.

Flagg, J. C.; Giroux, G. A.; and Wiggins, C. E. Jr. 1991. Predicting corporate bankruptcy using failing firms. Review of Financial Economics 1: 67-78.

Flood, R. and Marion, N. 1998. Perspectives on the Recent Currency Crisis Literature. NBER Working Paper No. 6380.

Gilbert, L. R.; Krishnagopal, M.; and Schwartz, K. B. 1990. Predicting bankruptcy for firms in financial distress. Journal of Business Finance and Accounting 17 (Spring):161-171.

Glick, R. and Rose, A. K. 1998. Contagion and trade: Why are currency crises regional? NBER Working Paper No. 6806.

Hopwood, W.; McKeown, J. C. ; and Mutchler, J. F. 1989. A Test of the incremental explanatory power of opinions qualified for consistency and uncertainty. The Accounting Review 66:28-48.

Johnsen, T. and Melicher, R. W. 1994. Predicting Corporate bankruptcy and financial distress: information value added by multinomial ligit models. Journal of Economics \& Business 46:269-286. 
Kaminsky, G. and Reinhart, C. M. 1996. The Twin crises: The causes of banking and balance-of-payment problems. Federal reserve board and international monetary fund. Unpublished Manuscript.

Kaminsky, G.; Lizondo, S.; and Reinhart, C. M. 1997. Leading indicators of currency crises. International monetary fund. Working Paper.

La Porta, R.; Lopez-de-Silanes, F. ; Shleifer, A.; and Vishny, R. W. 1998. Law and finance. Journal of Political Economy, forthcoming.

Maddala, G. S. 1986. Econometric issues in the empirical analysis of thrift institutions' insolvency and failure. Invited Research Working Paper 56, Federal Home Loan Bank Board, October.

Mensah, Y. M. 1983. The differential bankruptcy predictive ability of specific price level adjustments: Some empirical evidence. The Accounting Review LVIII(April):228-246.

Ohlson, J. A. 1980. Financial ratios and the probabilistic prediction of bankruptcy. Journal of Accounting Research 18(Spring):109-130.

Platt, H. E. and Platt, M. B. 1990. Improving ex ante bankruptcy classification using stable predictive variables. Journal of Business Finance and Accounting 17:31-51.

Platt, H. E. and Platt, M. B. 1991. A note on the use of industry-relative ratios in bankruptcy prediction. Journal of Banking and Finance 15:1183-1194.

Poston, K. M.; Harmon, W. K.; and Gramlich, J. D. 1994. A test of financial ratios as predictors of turnaround versus failure among finanially distressed firms. Journal of Applied Business Research 10: 41-56.

Rachel, S. and Sachs, J. 1998. The onset of the east Asian financial crisis. NBER Working Paper No. 6680.

Rose, R. S.; Andrews, W. T.; and Giroux, G. A. 1982. Predicting business failure: A macroeconomic perspective. Journal of Accounting, Auditing, and Finance (Fall): 20-31.

Salchenberger, L. M.; Cinar, E. M.; and Lash, N. A. 1992. Neural networks: A new tool for predicting thrift failures. Decision Sciences 23: 899-916.

Scott, J. 1981. The probability of bankruptcy: A comparison of empirical prediction and theoretical model. Journal of Banking and Finance 5: 317344.

Shivaswamy, M.; Hoban, J. P.; and Matsumoto, K. 1993. A behavioral analysis of financial ratios. The Mid-Atlantic Journal of Business 29 (March) :7-24.

Theodossiou, P.; Kahya, E. ; Saidi, R.; and Philippatos, G. 1996. Financial distress and corporate acquisitions: Further empirical evidence. Journal of Business Finance and Accounting 23 (July): 699-719.

Thomson, J. B. 1992. Modeling the bank regulator's closure option: A two-step logit regression approach. Journal of Financial Services Research.

Zavgren, C. 1983. The prediction of corporate failure: The state of the art. Journal of Accounting Literature 2: 1-35.

Zmijewski, M. E. 1984. Methodological issues related to the estimation of financial distress prediction models. Journal of Accounting Research 22 (Supplement): 59-85. 